\title{
Javanese Cultural Practices Maintained in The Area of Transmigration Destination (Study on the Practice of Festivity in a Person's Life Circle in Takisung District, Tanah Laut Regency)
}

\author{
Eva Alviawati \\ Phd Student in Faculty of Geography \\ Gadjah Mada University \\ Yogyakarta, Indonesia \\ alviawati@gmail.com
}

\author{
Raden Rijanta \\ Faculty of Geography \\ Gadjah Mada University \\ Yogyakarta, Indonesia
}

\author{
Sri Rum Giyarsih \\ Faculty of Geography \\ Gadjah Mada University \\ Yogyakarta, Indonesia \\ Rika Harini \\ Faculty of Geography \\ Gadjah Mada University \\ Yogyakarta, Indonesia
}

\begin{abstract}
The transmigration program as part of the internal migration in Indonesia not only moves the population from the origin to the destination, but transmigration also displaces the inherent culture of the transferee through the transmigration program. This study aims to investigate the practices of Javanese culture related to Selamatan (communal feast accompanied with religious activities) in a person's life cycle which is still maintained at the transmigration site. Through qualitative survey method, the results of this study indicate that the Javanese tradition related to the salvation in a person's life cycle is still implemented in the transmigration destination areas, especially in the District of Takisung, Tanah Laut Regency.
\end{abstract}

Keywords- Javanese Culture, Salvation, Transmigration.

\section{INTRODUCTION}

Transmigration is one of the forms of internal migration that occurs in Indonesia. Transmigration is a planned migration, from the selection process of trans-migrants to their placement, and the various facilities for trans-migrants to allow planned migration to proceed smoothly. Transmigration is basically a movement between villagers, mostly from trans-migrants from villages in Java, Madura and Bali to the direction of agrarian frontier [1].
When the transmigration program is implemented, basically the program is not only apart from moving the population or community from the origin to the destination, but transmigration also moves a community culture attached to the person who follows the transmigration program, hereinafter referred to as the trans-migrant. Culture occupies a central position in the order of human life because culture is a product of human beings and human beings themselves are product of culture [2]. Culture in which values are stored is related to the human response to the world, environment and society, and become the basic foundation for determining attitudes toward the outside world and the basis for every taken step [3].

The Javanese are those who live in the Central part of Java (including Central Java and Yogyakarta) and East Java, as well as those who come from the area. Ref [4] provides an explanation related to the Javanese society that the Javanese society is a united society that is bounded by the norms of life because of history, tradition and religion [4]. Restrictions on Javanese culture by [5] the Javanese culture is a manifestation of the human mind of Javanese It includes willingness, ideals, ideas and passion for achieving welfare, safety and happiness outwardly and inwardly [6].

The description of Javanese society as mentioned earlier becomes important to be studied, especially in relation to the practice of celebration conducted by Javanese in the transmigration destination area to the present day. This 
study intends to examine how the practices of Javanese culture related to Selamatan in a person's life cycle are maintained at the transmigration site.

\section{LITERATURE REVIEW}

Ref [7] argued that Javanese society is one of the livings and developing society since ancient times until now who uses Javanese language in various dialects and they inhabit most of Java Island. The Javanese social system recognizes the various traditional ceremonies (celebration) in order to run the business of maintaining and developing the village community [8]. Kodiran in [9] classified the Selamatan ceremony into several kinds according to the events in everyday human life, namely: (1) celebration in the framework of a person's life cycle, such as seven months pregnancy, birth, first hair cutting ceremony, stepping on soil for the first time, rituals of ear piercing, circumcision, death, and moments after death; (2) festivity relating to clean village, cultivation of farmland, and after harvest of paddy; (3) festivity relating to the great days and months of Islam; (4) festivity at indefinite moments, concerning events such as making long journeys, occupying a new residence, denying danger (ngruwat), promises of recovery from illness and so on. Besides selamatan also often makes offerings (Kodiran in [9]).

The Javanese society is unique in terms of culture, etiquette and so on. However, it cannot be denied that the influence of science and technology has more or less undermined the uniqueness of the Javanese community especially among the younger generation. The Javanese people in some cities have begun to find that they no longer show their Javanese identity. Some of these societies tend to prefer a modern look that is not bound by any rules or traditions that are perceived as preventing forward.

Ref [10] in his book The Study of Man proposes a concept about the difference between the core part of a culture (covert culture) and the part of the overt culture. The core part refers to, for example, the system of cultural values, beliefs, beliefs which are considered sacred, some customs that have been studied very early in the process of socialization of individual citizens and some customs that have functions that netted widely in society. Covert culture is part of a culture that is slowly changing and fairly difficult to replace with foreign elements. On the other hand, the part that is born of a culture (overt culture), such as physical culture, such as useful tools and tools, science, procedures, lifestyle, and recreation are useful and provide security [11].

The method used in this study was a qualitative survey method using interview techniques and document studies in data collection. Interview was used as a method of collecting data by one-sided question and answer done systematically and based on the purpose of research. The researchers conducted question and answer with the parties who know "festivity of cultural practices that are still maintained at the transmigration site". In this research, there were 9 informants who were the generation of trans- migrants and community leaders in the village of Mount Makmur and Sumber Makmur Village Takisung District Tanah Laut Regency.

\section{RESUlTS AND DISCUSSION}

Selamatan is a form of thanksgiving by inviting some relatives or neighbors. Traditionally the thanksgiving ceremony starts with a prayer together, sitting cross-legged on a mat, around the rice cone and side dishes. Selamatan in the framework of life circle which until now is still done in transmigration destination areas include the village of Mount Makmur and Sumber Makmur Village, Takisung Sub-district as follows:

A. Festivity of seven-month pregnancy

In Javanese life when a woman undergoes a pregnancy especially for the first pregnancy, there is a ceremony held at the age of the fetus entering the seventh month. One of the 3rd generation of Javanese trans-migrants stated:

.....mitonicara tradisi Jowo isih nggae acara mandimandi nggae kain jarik tujuh lembar terus pantangane wong ngandung cara Jawa yo tak lakoni,..... (Ayu, 2017).

Ayu as a woman of Javanese descent said that while pregnant also carry out seven monthly festivity which is done in accordance with the age of the fetus up to seven months in Javanese called mitoni. In addition to conducting the ceremony mitoni, Ayu also does not do things that are considered taboo done by pregnant women.

\section{B. Birth Ceremony}

The birth of a baby in Javanese tradition is followed by a ceremony. The ceremony is called brokohan. The term brokohan comes from the Arabic language Barokah which means that the ceremony is intended to invoke the blessing and safety of the birth of a baby. During the brokohan event usually neighbors and relatives come together as a sign of happiness for the birth of a baby.

The next series of baby birth ceremonies is "Sepasaran". Sepasaran is a Javanese traditional custom done after five days since the birth of the baby. At the time of the event, the usual festivity conducted. The essence of this event is as a ceremony of selamatan once the name of a baby who has been born is announced.

When the umbilical cord attached to the baby's stomach has been broken off, then the bellows ceremony is performed. The ceremony is the implementation of a feast to appeal to God so that babies who have been pusutpuser are always blessed, given the safety and health. Some modern Javanese society members in carrying out a bellows event usually make in conjunction with a ceremony sepasaranus or selapanan, depending on when the umbilical cord broken off from the baby's navel.

After 35 days (selapan) counted since the birth of the baby, the selapanan ceremony is performed. The ceremony takes place with a series of wetonbancakan events (day of birth), cutting the baby's hair to bare and cutting the baby's nails. Bancakanselapanan is intended as a gratitude for the birth of a baby, as well as a prayer for the baby to be always 
given the health and various other good prayers. The entire series of birth ceremonies is still being held in the transmigration destination area in Takisung, as stated by Mrs. Adi, who came from KulonProgo Yogyakarta as follows:

......sedoyo tradisi ten Jawa nggih di laksanaaken ten mriki termasuk acara lairan nggih ngagem brokohan, sepasaran, selapanan...(Adi, 2017).

According to Mrs. Adi, all the traditions conducted in KulonProgo Yogyakarta related to the tradition of salvation are also carried out at the destination of transmigration.

\section{Circumcision Ceremony}

The tradition of circumcision ceremony or circumcision is performed for boys before puberty. The circumcision comes from the Arabic word "sunnah" which means that the person who does it follows the tradition (sunnah) of Prophet Muhammad SAW. Usually circumcision is done when the child is between 11-17 years old. The circumcision ceremony is held royally by the Javanese especially for those who have enough funds or are able to hold their preferred performances such as "kuda lumping ". One of the households who recently takes care of the circumcision of his son suggested:

....dek wingi pas khitanan yogane nggene kula juga nanggap jaranan....(Bar, 2017)

At the time of the circumcision ceremony of his son recently the Bar family held a show "Kuda Lumping" as a form of gratitude. Further related to the tradition of circumcision of the Javanese in the transmigration destination, the society also almost always make "Ingkung" for the event kenduri as stated by the following informant:

.....nek orang Jawa di sini setiap khitanan pasti bikin ingkung.....(Ayu, 2017)

Ingkung is one of the equipments in Javanese tradition, chicken cooked and spiced with opor, coconut and bay leaf. This symbol represents an unborn child thus still sacred. Ingkung is also interpreted as an attitude of surrender and give up to the power of God. Ingkung is meant to purify the people who have intent and guests who attended the ceremony [12].

\section{Marriage Ceremony}

The ancient Javanese community has a very complete procedure in the tradition of marriage. Javanese wedding tradition is usually divided into three periods, i.e. before the wedding, the day of implementation and after the wedding. In the pre-marriage stage, Javanese living in transmigrationled villages begin with nglamar, tukon and midadarenisupplies. On the day of marriage, marriage ceremony is held. After the wedding there is usually a boyongan or ngunduh ceremony. This tradition is also still done by the Javanese people in transmigration destination areas.

In a series of marriage ceremony, twins of wedding Mayang are made. Twin Mayang is a kind of bouquets from young coconut leaves (janur) with some kind of leaf and mayang flowers (Pinang flowers) or pudak flowers (like pandanus). The twins of Mayang are two pieces of the same shape and meaningful as the tree of life that can provide all the things desired. The twins of Mayang symbolize the flowering of areca nut whose meaning is ushering in the new life of the adult in society so that people can pluck the devotion and Dharmanya (Gondowasito (1965) and Sindoesastro (1938) in [13]). Figure 1 shows the process of making the twin mayang performed ahead of the Javanese customary marriage in the transmigration destination area.

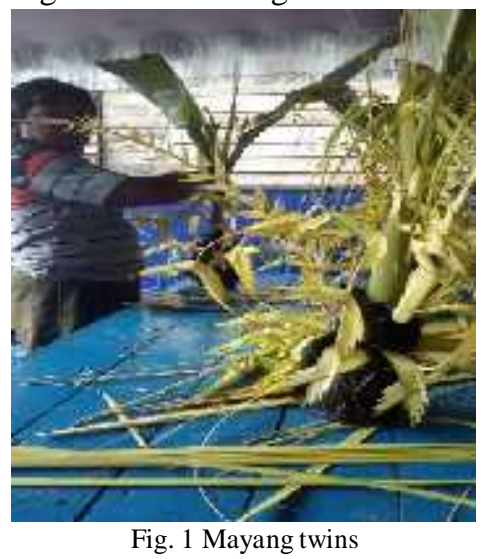

\section{E. Death ceremony and the time after death}

Selamatan death is one of the most important religious ceremonies in order to pray for the spirit that has proceeded to the almighty and preserve the hereditary traditions. The period and sequence of deaths ceremonial that are always carried out are as follows:

1) "Geblak" or selamatan after burial

"Geblak" or usually referred to as "ngesur tanah" is a ceremony held at the time of one's death. The ceremony is held in the afternoon after the corpse is buried. Selamatan ngesur this land is symbolized by making tumpeng pungkur as stated by the following informants:

....tumpeng pungkur kagem simbul pisahing rogo lan sukmo di damel pas pembukaan (ngesur tanah) kalian pungkasan (sewunan).....(Joyo, 2017).

Joyo suggests that Tumpeng Pungkur is the symbol of the separation of soul and body.

2) Selamatan after three days of death or "nelungdino"

The implementation of this selamatan is usually done before the third day. It is intended as the heir's attempt to honor the deceased spirit. According to Javanese belief at that time the spirit who has died is still in the house.

\section{3) Selamatan after seven days of death.}

This salvation is often referred to as "mitungdina". After seven days, it is believed the spirits start to come out of the house. To ease the journey of the spirit for leaving the heir home, the tahlilanactivity is conducted and pray for the sins of the deceased to be forgiven. On the selamatan after seven days of death, the participants are given a sodaqoh delicacy containing rice and side dishes. 


\section{4) Selamatan 40 days after death}

This selamatan is often called "matangpuluhdina". This tradition is meant to facilitate the journey of the spirit to the grave. Heirs assist by sending prayers that is by reading tahlil and selamatan.

5) Selamatan after 100 days of death

This salvation is often called "nyatusdina". The Javanese people believe that in the grave the spirit still often returns to the family until the first and second year commemorative ceremonies.

\section{6) Salvation after one year of death (Mendhaksepisan)}

The ceremony is held in the first year after the death. It is intended to recall the merits of the deceased. Salvation "mendhakpisan" is also called "meling". The word "meling" comes from the word "eling" which means to remember.

\section{7) Selamatan after two years of death}

This salvation is often referred to as"mendakpindho", intended to perfect all skin, blood and such. At this moment the body has been destroyed just left the bones alone [6]. In this ceremony the prayer is sent by tahlil and the dish of selamatan.

\section{8) Selamatan after a thousand days of death}

This selamatan is called the "nyewu", which is said to be the culmination of a series of death deaths. The Javanese believe that at this moment the human spirit who has died will not return to the midst of their family again.

Various ceremonies of selamatan in the circle of life are still preserved in transmigration destination areas either by first generation trans-migrants or their descendants. This is in accordance with one of the second generation of transmigrants who said:

.....kula tasih nglaksanaken tradisi Jawa sing di ajarke tiyang sepuh kula, anak kula ugi tasih nglaksanaken tradisi menika.....(Warsono, 2017).

Warsono suggests that he and his children still practice the Javanese tradition as taught by their ancestors. Furthermore, in the implementation of the selamatan, the Javanese in the transmigration destination area still calculates the existence of good days especially for the circumcision and marriage, as stated by the informant as follows:

.....petungan jawi nggih tasih diagem nek badhe nyunatke yogane nopo nikahke, mulane kedah di elingeling dinten wetone yogane kabeh....(Yah, 2017).

Yah stated that he still uses the calculation of a good day in the Javanese tradition when determining the day to carry out circumcision and marriage of his son. In line with this, the other informant suggested:

....nek kula mboten saget ngetung dinten sae, ning tiyang mriki asring nyuwun bantuanipun mbah Arjo kagem ngitungke dinten sing sae...(Yuli, 2017).

Yuli claimed that she cannot do a good day's calculation, so she asks for help from one of the community leaders to calculate the good day.

\section{CONCLUSION}

"Selamatan" is a form of gratitude towards the Creator of life. Being grateful will make the soul of the person who does it happy. The holy tradition or ceremony performed by the Javanese who live in the transmigration destination is not only a habit but also a symbolic event to always be grateful for all the grace given and also to pray to always be given safety and health.

The Javanese who live in transmigration destination areas in Takisung District still maintain a tradition of selamatan in their daily lives. They involve the younger generation in every event of selamatan so that directly or indirectly they have made an effort to inherit the values of tradition between generations. However, there are also Javanese people who have started to ignore this tradition, so in-depth research using case studies needs to be conducted to examine the implementation of Javanese cultural traditions at the location of transmigration.

\section{REFERENCES}

[1] S.Rusli, Pengantar Ilmu Kependudukan, Cetakanke 5 Jakarta: LP3ES, 1989.

[2] R.R Maran,Manusia dan Kebudayaan Dalam Perspektif Ilmu Budaya Dasar, Jakarta: PT. Rineka Cipta, 2000

[3] B.Herusatoto, Simbolisme dalam Budaya Jawa, Yogyakarta: Hanindita Graha Widia, 2000.

[4] Ismawati, "Budaya dan Kepecayaan Jawa Pra Islam" dalam Darori, Amin (ed), Islam dan Kebudayaan Jawa, Yogyakarta: Gama Media, 2002.

[5] K.Kamajaya, Serat Centhini Latin Jilid I, V, VI, VII, 1995

[6] T.W.Bratawidjaja, Upacara Tradisional Masyarakat Jawa, Jakarta: Pustaka Sinar Harapan, 1993.

[7] B. Herusatoto, Simbolisme dalam budaya Jawa, 1984

[8] M.Ideham, Suriansyah, Urang Banjar dan Kebudayaannya, Yogyakarta: Penerbit Ombak, 2015.

[9] Koentjaraningrat, Manusia dan Kebudayaan di Indonesia, Djambatan: Jakarta, 1971

[10] R.Linton, "The study of man: an introduction," (1936)

[11] Koentjaraningrat, Beberapa pokok antropologi sosial, Dian Rakyat, 1990.

[12] W.Giri, Sajen dan ritual orang Jawa, Penerbit Narasi, 2010.

[13] S.Widayanti, 2008, Makna Filosofis Kembar Mayang Dalam Kehidupan Masyarakat Jawa, Jurnal Filsafat, Vol.18(2), August 2008. 